\title{
A CLINICAL STUDY TO IDENTIFY THE PREVALENCE OF ASYMPTOMATIC BACTERIURIA IN TYPE II DIABETIC PATIENTS AT RAJIV GANDHI INSTITUTE OF MEDICAL SCIENCES, SRIKAKULAM
}

\author{
Bongu Srinivasa Rao1, A. Gopal Rao², Sharath Babu Naik Z \\ ${ }^{1}$ Associate Professor, Department of Medicine, RIMS, Srikakulam. \\ ${ }^{2}$ Associate Professor, Department of Medicine, RIMS, Srikakulam. \\ ${ }_{3}^{3}$ Assistant Professor, Department of Community Medicine, RIMS, Srikakulam.
}

\begin{abstract}
BACKGROUND
Diabetes mellitus is one of the common diseases affecting a large number of population throughout the world.(1) Urinary tract infection is the most common infection in diabetic patients. Many UTIs are asymptomatic and whether symptomatic UTI are preceded by asymptomatic bacteriuria (ASB) is not known. Asymptomatic bacteriuria can lead to symptomatic urinary infection as well as increase in tendency for chronic kidney disease (CKD) and renal failure as one of the long-term adverse effects. The prevalence rate of ASB in diabetic women are $9 \%-29 \%$ among females and $0.7 \%-11 \%$ in males. $(2,3)$ The most common aetiological agents $(4,5,6)$ in asymptomatic bacteriuria are Klebsiella pneumonia, E. coli, Enterobacter spp., Streptococcus agalactiae, Enterococcus faecalis, Coagulase Negative Staphylococci (CONS) and Streptococcus pyogenes. UTI is a common problem among females and non-diabetics also, hence a study was conducted to know the asymptomatic bacteriuria among type 2 diabetics and non-diabetics.
\end{abstract}

ABSTRACT

\section{MATERIALS AND METHODS}

Outpatients attending medicine OPD in Rajiv Gandhi Institute of Medical Sciences, Srikakulam, were taken into the study. A crosssectional study was done to know the prevalence of asymptomatic bacteriuria in Type II Diabetic patients among the diabetics (Group A) and non-diabetics (Group B); 103 patients in study population (Group A) and 50 patients in control group (Group B) were taken; $50 \%$ of the sample size were taken for control group.

\section{RESULTS}

Out of 153 randomly selected patients 103 were found to be diabetic; hence, they were recruited in the study group. Out of 103 patients, $58(56.3 \%)$ were females and $45(77 \%)$ were males in the study population. All the patients were in the age group of $30-$ 80 years with an age of $42 \pm 10.6$ years (Table 1) (Graph 1). Non-diabetic 50 patients were included in the control group, who were in the age group of 75 years with the mean age of $48 \pm 8.9$ years. Control group consisted of 28 (56\%) males and $22(44 \%)$ females.

\section{CONCLUSION}

The incidence and prevalence of ASB is high in diabetic population compared to non-diabetic group.(5) ASB is one of the important risk factors for renal complications in Diabetic population. Diverse pathogenic microbial diaspora are responsible for ASB. Close monitoring of antibiotic sensitivity shall improve the control of ASB and thereby score over the risk reduction of renal complications in diabetic patients. To prevent lifetime complications, it is recommended periodic/ regular screening for UTI as it has a symptomatic presentation.

\section{KEYWORDS}

ASB (Asymptomatic Bacteriuria), Microbiological Examination, Microscopy, Culture and Gram Stain.

HOW TO CITE THIS ARTICLE: Rao BS, Rao AG, Naik SBZ. A clinical study to identify the prevalence of asymptomatic bacteriuria in type II diabetic patients at Rajiv Gandhi Institute of Medical Sciences, Srikakulam. J. Evolution Med. Dent. Sci. 2018;7(03):376-379, DOI: $10.14260 /$ jemds/2018/83

\section{BACKGROUND}

Diabetes mellitus is one of the common diseases affecting a large number of population throughout the world. It is an endocrine disorder affecting the physical, psychological and social health of an individual. Urinary tract infection is the most common infection in diabetic patients.(6) Many UTIs are asymptomatic, and whether symptomatic UTIs are preceded by asymptomatic bacteriuria (ASB) is not known.(2)

'Financial or Other Competing Interest': None.

Submission 13-11-2017, Peer Review 31-12-2017,

Acceptance 06-01-2017, Published 13-01-2018.

Corresponding Author:

Dr. Sharath Babu Naik Z,

Assistant Professor,

Department of Community Medicine,

RIMS, Srikakulam.

E-mail: bhavyabongu@gmail.com

DOI: $10.14260 /$ jemds $/ 2018 / 83$

\section{(c) (i) $($ ) $\ominus$}

Diabetes is more common in India, China and USA. Asymptomatic bacteriuria precedes symptomatic UTI in many occasions in type 2 diabetes.(7) The presence of higher glycated haemoglobin levels was the only significant risk factor for significant bacteriuria in women with type 2 diabetes. ${ }^{(8)}$
Aim of the Study
- $\quad$ To identify the prevalence of asymptomatic bacteriuria in type II diabetics and non-diabetics.
- To know the bacterial profile of ASB.

\section{MATERIALS AND METHODS}

Outpatients attending medicine OP in Rajiv Gandhi Institute of Medical Sciences Research Institute, Srikakulam, were taken for the study. It is a cross-sectional study to know the prevalence of asymptomatic bacteriuria in type 2 diabetic patients and non-diabetics. 


\section{Study Period}

1 year.

\section{For Group A (Type 2 Diabetics)}

\section{Inclusion Criteria}

1. Patients with age $>18$ years or above.

2. Both sexes.

3. Newly diagnosed cases with Type 2 diabetes mellitus with fasting $>126 \mathrm{mg} / \mathrm{dL}$.

4. Not on any anti-diabetic treatment.

\section{Exclusion Criteria}

- Pregnant women.

- Recent urethral catheterisation.

- Immunocompromised patients (HIV, Malignancy, Longterm steroid therapy).

- Recent hospitalisation or undergone surgery within past 6 months or undergone any urogenital procedures.

- Patients with fever, chills or pain in abdomen were excluded from the study.

\section{For Group B (Non-Diabetics)}

\section{Inclusion Criteria}

1) Not a known diabetic.

2) Aged $>18$ years.

3) Not having any three of cardinal symptoms of diabetes.

4) Fasting blood sugar $<100 \mathrm{mg} / \mathrm{dL}$.

5) Not having any other known chronic diseases.

\section{Exclusion Criteria}

- Pregnant women.

- Recent urethral catheterisation.

- Immunocompromised patients (HIV, malignancy, longterm steroid therapy).

- Recent hospitalisation or undergone surgery within past 6 months or undergone any urogenital procedures.

- Patients with fever, chills or pain in abdomen were excluded from the study.

\section{Collection of Urine Sample}

All patients were asked to collect clean catch midstream urine sample, and presence of pus cells and pyuria were examined, and urine culture was done.

\section{Sample Size}

All the newly diagnosed diabetic patients attending the Medicine Department OPD, who were not having any other complaints requiring antibiotics were listed for the said period. Total 257 newly diagnosed Type 2 patients were listed and after exclusion criteria and convenience sampling method 150 were included and of them 120 gave consent. 17 individuals were lost to follow-up and hence 103 individuals were retained and were labelled as Group A, i.e. Type 2 diabetic patients.

For Control, a convenience sample of 50 were chosen and shortlisted based on the inclusion criteria and majority of them were patient attendants or relatives etc. who volunteered were taken for the control group and labelled as Group B, i.e. non-diabetic individuals.
103 randomly selected study group patients and 50 randomly selected control group attending outpatient were of Rajiv Gandhi Institute of Medical Sciences, Govt. General Hospital, Srikakulam who were above 18 years of age were explained about the study and they gave written consent to participate in the study.

\section{Laboratory Methods $(9)$}

The patients were instructed to clean their genital area with soap and water and to leave the first part of the urine and collect $10 \mathrm{~mL}$ of the clean catch midstream urine in smile container. The urine samples were immediately transported to laboratory and were processed immediately. In case of daily, the samples were stored in $4^{\circ} \mathrm{C}$ in the refrigerator or preservative like boric acid were added. In addition to culturing, quantitative bacterial count, microscopic examination and routine biochemical analysis for diabetic patients were done. Macroscopic analysis of urine samples was done to describe the urine colour, specific gravity, $\mathrm{pH}$, glucose, protein, ketone, RBC's etc.

\section{Biochemical Examination}

24 hours urine samples were collected to find the urine albumin level, excretion of urea. Creatinine was done by Jaffe's method Analysis in Department of Biochemistry, MMCH and RI. $5 \mathrm{~mL}$ of blood was collected to test for the fasting, post-prandial glucose level, serum creatinine level, and blood lipid profiles such as HDC, LDL, VLDL and triglycerides level. Micro-albuminuria, macro-albuminuria and $\mathrm{HbA1c}$ were done using Miphlometry analysis.

\section{Microbiological Examinations \\ Microscopy}

Urine samples were centrifuged at $500 \mathrm{rpm} / 5 \mathrm{mins}$. A wet mount and gram stain was done to detect the presence of $>10$ pus cells and bacteria. Presence of $>10$ polymorph nuclear leucocytes/ HPF indicated inflammation of urinary culture: Significant bacteriuria was assessed using standard loop technique ( $\left.\geq 10^{5} \mathrm{CFU} / \mathrm{mL}\right)$.

The samples were streaked on various media such as nutrient agar, blood agar, MacConkey agar and incubated at $37^{\circ} \mathrm{C}$ for 24.48 hours and presence of visible colony formation was noted.

\section{Renal Complication}

Ultrasound scanning was done to find any renal scars or renal damage. Two views of anterior and posterior scan views were taken for finding the presence of cortical indentation and focal or multiple defects, either unilaterally or bilaterally was recorded as abnormal.

$\begin{array}{lll}\text { Normal albuminuria } & - & \text { UACR }<30 \mathrm{mg} / \mathrm{g} . \\ \text { Micro albuminuria } & - & \text { UACR } 30-299 \mathrm{mg} / \mathrm{g} . \\ \text { Macro albuminuria } & - & \text { UACR } 300 \mathrm{mg} / \mathrm{g} \text { or more. }\end{array}$

\section{Statistical Method}

Statistical analysis was performed using Microsoft (MS) Office Excel software. 


\section{RESULTS}

Out of 103 patients 58 (56.3\%) were females and 45 (77\%) were males in the study population. All the patients were in age group of $30-80$ years with an age of $42 \pm 10.6$ years (Table 1) (Graph 1).

Non-diabetic 50 patients were included in the control group who were in the age group of 75 years with mean age of $48 \pm 8.9$ years. Control group consists of $28(56 \%)$ male and females 22 (44\%).

\begin{tabular}{|c|c|c|}
\hline \multirow{2}{*}{$\begin{array}{c}\text { Age } \\
\text { (Years) }\end{array}$} & Male (N= 45) & Female (N= 58) \\
\cline { 2 - 3 } & $9(20 \%)$ & $14(24.1 \%)$ \\
\hline $45-45$ & $21(50 \%)$ & $28(48.3 \%)$ \\
\hline $55-55$ & $4(9.5 \%)$ & $5(8.6 \%)$ \\
\hline $65-65$ & $9(21.4)$ & $7(12.1 \%)$ \\
\hline $75-85$ & $2(4.8 \%)$ & $4(6.9 \%)$ \\
\hline \multicolumn{2}{|c|}{ Table 1. Age and Sex-Wise distribution of Study } \\
Group of Patients
\end{tabular}

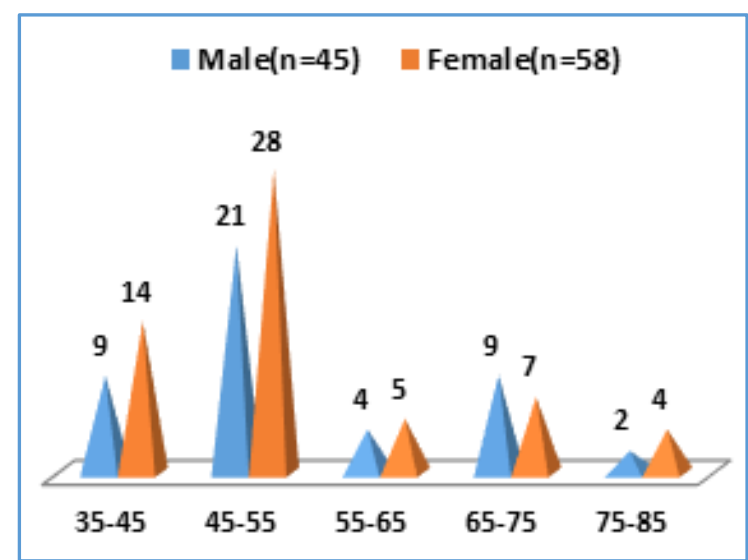

Graph 1. Age and Sex-Wise distribution of Study Group (Type 2 Diabetics)

Out of 103 diabetic patients screened, 29 (28.2\%) had asymptomatic bacteriuria in study population.(10) In control group non-diabetic patients out of 50 only $4(8 \%)$ were asymptomatic, but 14 (28\%) had symptomatic UTI (Table 3) (Graph 3). Among 29 patients with asymptomatic bacteriuria, 18 (62.06\%) were female and 11 (37.94\%)(11) were male patients in the age group of 42 - 60 years.

Similar screening done on 50 individuals from the study group B $4(8 \%)$ were found to have asymptomatic bacteriuria, in which $3(75 \%)$ were females and 1 (25\%) was a male patient (Graph 2).

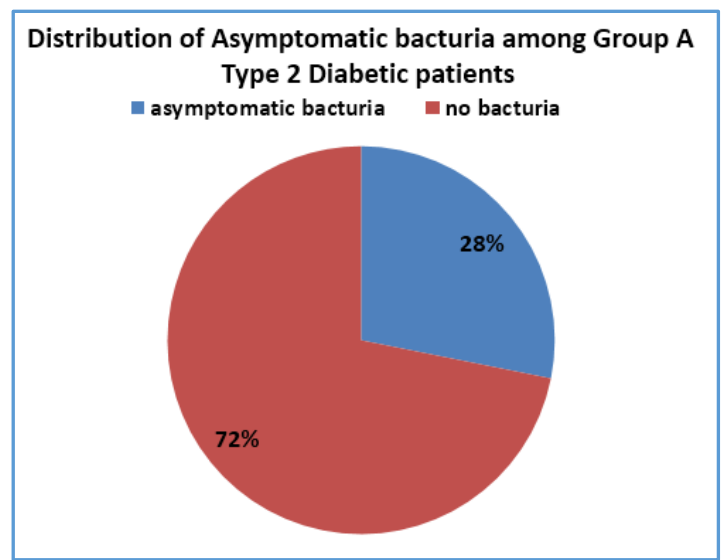

Distribution of Asymptomatic bacturia among Group B Non-Diabetic individuals

asymptomatic bacturia $\quad$ no bacturia

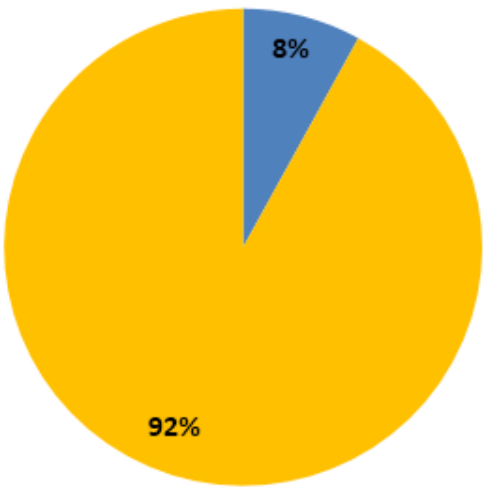

The most common uropathogens isolated from the study Group A (Type 2 Diabetes Mellitus) are E. coli with 13 (44.8\%) followed by Pseudomonas aeruginosa 4 (13.8\%), Proteus mirabilis with $3(10.3 \%)$ and Proteus vulgaris 3 (10.3\%), Acinetobacter 2 (6.9\%), Enterococcus faecalis 2 (6.9\%) and Candida albicans 2 (6.9\%)

In control group, among 50 urine sample $3(75 \%)$ were E. coil and Klebsiella 1 (25\%).

\section{DISCUSSION}

The association of ASB with albuminuria and creatinine level has a significant correlation, which is concordant with our study, which also shows significant association of albuminuria and serum creatinine level in ASB. There was no correlation between age, BMI and ASB among the diabetic patients, which is similar to a study who also reported that there is no correlation between ASB with age and BMI of the patients. The mean glycaemic level of diabetic patients at the time of inclusion into the study was $>7.2 \pm 1.8$.

It is suggested that ASB leads to increase in frequency of complications such as pyelonephritis, emphysematous cystitis, emphysematous pyelonephritis, perinephric abscess, renal papillary necrosis and renal failure.

The rate of diabetic glomerulopathy prevalence was $10.7 \%$ and $4 \%$, which need a renal biopsy to be performed. Patients with significant albuminuria UACR $>30 \mathrm{mg} / \mathrm{g}$ were the main markers to diagnose glomerulopathy. Increased albumin excretions and inflammation of the kidney are the associated factors leading to chronic kidney disease in type 2 diabetic patients. These results imply that damage to the kidney may be due to high incidence of recurrent ASB, which makes kidney vulnerable for bacterial infections which in turn declines the renal function.

\section{CONCLUSION}

- $\quad$ Out of 103 patients in group A (Type 2 Diabetics) of studied patients, $58(56.3 \%)$ were females and 45 $(43.7 \%)$ were males in this group. They were in the age group of $30-80$ years with mean age of $42 \pm 10.6$ years.

- Of the 50 individuals from the group B (non-diabetics), $28(56 \%)$ were males and 22 (44\%) were females in the age group of $25-70$ years with mean age of $48 \pm 8.9$ years $29(28.2 \%)$. 
- $\quad$ Asymptomatic bacteriuria consisted of 3 (75\%) female and $1(25 \%)$ male patients in the age group of $42-60$ years in non-diabetic group.

- $29(28.1 \%)$ had asymptomatic bacteriuria that consisted of $18(62 \%)$ males and $11(38 \%)$ females in study population group A (Type 2 Diabetic Mellitus).

- In group B (non-diabetic individuals), only 4 (8\%) were asymptomatic with $3(75 \%)$ females and $1(25 \%)$ male patients.

- Nephropathy was diagnosed in $11(10.7 \%)$ in study group A type 2 diabetic mellitus population and $1(2 \%)$ group B in non-diabetic population.

- $\quad$ Neuropathy was seen in 4 (3.9\%) studied group A (Type 2 Diabetic Mellitus) population and $1(2 \%)$ in group B (non-diabetes).

- The most common uropathogens isolated from study group A (Type 2 Diabetic Mellitus) are E. coli followed by Pseudomonas aeruginosa $4(13.8 \%)$.

- In non-diabetics, the most common uropathogens isolated were E. coil and Klebsiella.

\section{REFERENCES}

[1] World Health Organization. Definition, diagnosis and classification of diabetes mellitus and its complications. Report of a WHO consultation Geneva: World Health Organization: 1999.

[2] Ophori EA, Imade P, Johnny EJ, et al. Asymptomatic bacteriuria in patients with diabetes. J Bacteriol Research 2010;2(2):14-7.
[3] Kutty VR, Soman CR, Joseph A, et al. Type 2 diabetes in southern Kerala: variation in prevalence among geographic divisions within a region. Natl Med J India 2000;13(6):287-92.

[4] Baqai R, Aziz M, Rasool G. Urinary tract infection in diabetic patients and biofilm formation of uropathogens. Infect Dis J Pak 2008;17(1):21-4.

[5] Ooi ST, Frazee LA, Gardner WG. Management of asymptomatic bacteriuria in patients with diabetes mellitus. Ann Pharmacother 2004;38(3):490-3.

[6] Patel DK, Kumar R, Laloo D, et al. Natural medicines from plant source used for therapy for diabetes mellitus: an overview of its pharmacological aspects. Asian Paci J Tro Dia 2012;2(3):239-50.

[7] Sharkey TP, Root HF. Infection of the urinary tract in diabetes. JAMA 1935;104(25):2231-5.

[8] Bonadio M, Boldrini E, Forotti G, et al. Asymptomatic bacteriuria in women with diabetes: influence of metabolic control. Clin Infect Dis 2004;38(6):e41-5.

[9] Kramer A, Schwebke I, Kampf G. How long do nosocomial pathogens persist on inanimate surfaces? A systematic review. BMC Infect Dis 2006;6:130.

[10] Geerlings SE, Stolk RP, Camps MJ, et al. Asymptomatic bacteriuria may be considered a complication in women with diabetes. Diabetes Care 2000;23(6):7449.

[11] Boroumand MA, Sam L, Abbasi SH, et al. Asymptomatic bacteriuria in type 2 Iranian diabetic women: a cross sectional study. BMC Women's Health 2006;6:4 